doi: 10.18575/msrs.sm.e.17.13

UDC 616.24-006.6

COBISS.RS-ID 6831640

\title{
Relationship between the Type of Non-Small Cell Lung Cancer and Infiltration of Lymphatic Drainage
}

\begin{abstract}
Introduction: Malignant cells invasion of lymphatic drainage represents the basic precondition of metastasis and the disease progress. The invasion of tumor depends on its pathomorphologic characteristics, out of which one of the most significant role is the type.
\end{abstract}

Aim of the Study: Descriptive analysis of operated patients, estimation of frequency and representativeness of the stated types of NSCLC in the monitored group, analysis of malignant cells of lung cancer in lymphatic drainage on the basis of the type of primary tumor.

Patients and Methods: The study included 331 patients, who underwent the surgery during which the malignant infiltration was removed, in addition to the dissection of lymph nodes drainage.

Results: Out of the total number of operated patients, 257 of them were male gender, while 74 were female gender, with the average age of 63.52 years (21-80). The relation of gender structure of the patients in relation to gender was statistically significant $(\mathrm{p}=0.00)$. The ratio between squamous cell carcinoma to adenocarcinoma was 182:140, while the other types of tumor were insignificant. Statistically, there was no significant difference in the frequency of two most common types of lung cancer ( $x^{2}$ test $=3.02 ; p=0.09$ ). There was no statistically significant connection between the type of tumor and $\mathrm{N} 1$ metastasis $\left(\chi^{2}=1.55 ; p=0.46\right)$, as well as in the ratio between the type of tumor and malignant infiltration of lymph nodes, level N2 $\left(x^{2}=2.33 ; p=0.32\right)$.

Conclusion: There is no connection between the type of lung cancer and invasion of levels N1 and N2 of lymph nodes.

Key words: N NSCLC, type of tumor, lymph nodes

(Scr Med 2017:48:96-10o)
Kemal Grbić,

Ademir Hadžismailović ${ }^{1}$ Dalma Udovčić-Gagula ${ }^{2}$, Marko Kantar ${ }^{3}$, Marinko Domuzin 4

${ }^{1}$ Clinic for Thoracal Surgery, $\mathrm{KCU}$ in Sarajevo, Sarajevo, BiH

${ }^{2}$ Department of Pathology, $\mathrm{KCU}$ in Sarajevo, Sarajevo, BiH

${ }^{3}$ Department of Thoracic Surgery, UKC of Republic of Srpska,

Banjaluka, BiH

${ }^{4}$ Clinic of Traumatology, University Clinical Centre of Republic of Srpska, Banjaluka, BiH

\section{Contact address:}

Kemal Grbić

Clinic for Thoracal Surgery

University Clinical Center Sarajevo, $\mathrm{BiH}$

Street address: Bolnička 25, 71000 Sarajevo,

Bosnia and Herzegovina phone number: $+387-33-297-238$ mob: +387-61-79o-994 e-mail:kemalgrbic@hotmail.com 


\section{Introduction}

According to all statistical data and relevant data basis, non-small cell lung cancer (NSCLC) is a disease with a permanent increase of frequency of morbidity and mortality, and it represents a big health issue of our time. It is the second most frequent detected cancer in male gender and also the first cause of death, while it is the third most frequent malignant tumor in female gender and the third most frequent malignant cause of death. ${ }^{1-3}$ In the past, the most common cancer was the one of discus respirationary epithelium, while according to the latest reports, a part of malignancy of lymphatic origin has reached $40 \%$ from the total number of new cases. ${ }^{4}$ The third, significantly smaller types are the remaining macrocellular tumors and transitive forms.

As it is a systematic disease, the first modern pathohistological classification of lung cancer was published by the World Health Organization (WHO) in 1952 and until now, it has been revised for several times. Multidisciplinary classification proposed by the International Agency for the Study of Lung Cancer (IASLC), the American Thoracic Society (ATS) and the European Respiratory Society (ATS) from 2011 is presently valid. The latter was approved by WHO, it has been valid since January 2015 and according to it, the tumors of this group have been classified into three sorts. ${ }^{5,6}$

According to the above mentioned classification, the most redefined is adenocarcinoma which is divided in three subgroups (preinvasive lesions, invasive adenocarcinoma with constructive predominations and rare forms of adenocarcinoma). Planocellular and other types of carcinoma also had small redefining. Each of the mentioned type of NSCLC has additional pathomorphological characteristics and invasion, which is demonstrated in its tendency to penetrate the basal stroma, lymph vascular infiltration, and lymphogenic and hematogenic metastasis..$^{5-7}$

According to the presently valid, The Eight Edition of the TNM Classification of Malignant Tumors, approved by WHO and which has been valid since January 2017, "N" parameter represents the presence/absence of malignant cells lymphatic drainage, and is therefore, in a phase of disease, significant in both therapy and prognosis. In relation to the previous classiffication from 2010, it has remained unchanged, apart from a descriptive grouping of nodes in already valid numeral positions, and it actually represents the Naruke map, which was reviewed by Mointana and Dresler in 1996. Infiltration of drainage nodes by tumor (N1-2) represents a precondition for dissemination, while level N3 represents a progressed level of the disease and contraindication for surgical treatment. ${ }^{-11}$

\section{Aim of the Study}

The aim of this study is a descriptive analysis of operated patients, estimation of frequency and representativeness of the stated types of NSCLC in the monitored group, analysis of malignant cells of lung cancer in lymphatic drainage on the basis of the type of primary tumor, and a display of statistical dependence of the noted variables.

\section{Patients and Methods}

This analysis included 331 patients who were operationally treated at the Clinic for Thoracic Surgery UKC in Sarajevo, with the application of some of the thoracosurgical operational procedures, during which, apart from the tumor removal, a disection of lymphatic drainage was also performed. All the patients were preoperationally diagnosed and they belonged to a clinical level cTNM Ia, Ib, IIa, Iib. Cases of level IIIa were also selected. The analysis excluded the patients who were pre-operationally treated by neoadjuvant therapy.

The data needed for this research were obtained from the history of disease, operational protocols and on the basis of defined pathohistological post-resectional analysis, which were done at the Department for Cytology and pathology at UKC in Sarajevo, and they minimally contained concretely defined type of tumor and patohistological status of drainage lymph nodes.

The results are demonstrated descriptively, numerically, in charts and in graphics with legends and textual description of certain obtained values and variables. The data were analyzed by demonstration of absolute values and values expressed in percentage, and by calculation of the arithmetic means and standard deviation. Nonparameter data were analyzed by chi-square test. The given level of statistical significance was ( alfa) $\mathrm{p}<0.05$. 


\section{Results}

Chart 1. Descriptive statistic of the age of the operated patients according to gender

\begin{tabular}{|cccc}
\hline $\begin{array}{c}\text { Descriptive } \\
\text { statistics }\end{array}$ & Male gender & $\begin{array}{c}\text { Female } \\
\text { gender }\end{array}$ & Total \\
\hline $\begin{array}{c}\text { Frequency (f/N) } \\
\text { Arithmetic mean } \\
\text { (AM) }\end{array}$ & 257 & 74 & 331 \\
\hline $\begin{array}{c}\text { Standard mistake } \\
\text { AS }\end{array}$ & 0.41 & 1.10 & 0.41 \\
$\begin{array}{c}\text { Standard } \\
\text { deviation (SD) }\end{array}$ & 6.63 & 9.32 & 7.47 \\
$\begin{array}{c}\text { Minimal (age) } \\
\text { Maximum (age) }\end{array}$ & 42 & 21 & 21 \\
\hline
\end{tabular}

By using T-test on the independent samples, the age of all patients who operated non-small cell lung cancer in relation to the gender structure (male/female), the final result was that the value of it was $\mathrm{p}=0.00$.

Confirmed average difference between the genders (3.71 years), Independent Samples Test-, was statistically significant, that is, there was a statistical significance in age between males $(\mathrm{M}=63.52 ; \mathrm{SD}=6.63)$ and females $(\mathrm{F}=59.81 ; \mathrm{SD}=9.32)$.

Graph 1. shows the frequency of lung cancer in numerical value and value in percentage, according to definite pathohistological diagnosis:

\section{Graph 1. The frequency of lung cancer according to definite pathohistological diagnosis}

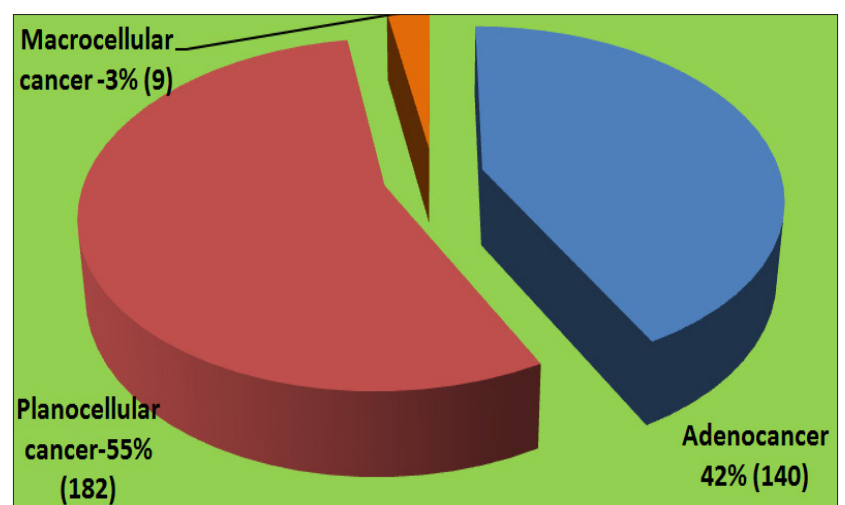

Statistically, there was no significant difference in the frequency between the two types of lung cancer ( $x^{2}$ test=3.02; $\mathrm{p}=0.09$ ).

The volume of invasion of $\mathrm{N} 1$ level of lymph nodes by metastatic deposits in lung cancer was 44.61\% (147/331), while they were negative in $55.39 \%$ of patients (184/331) patients, which is shown in the Graph 2.

Graph 2. Frequency of $\mathbf{N} 1$ metastasis in relation to the type of tumor

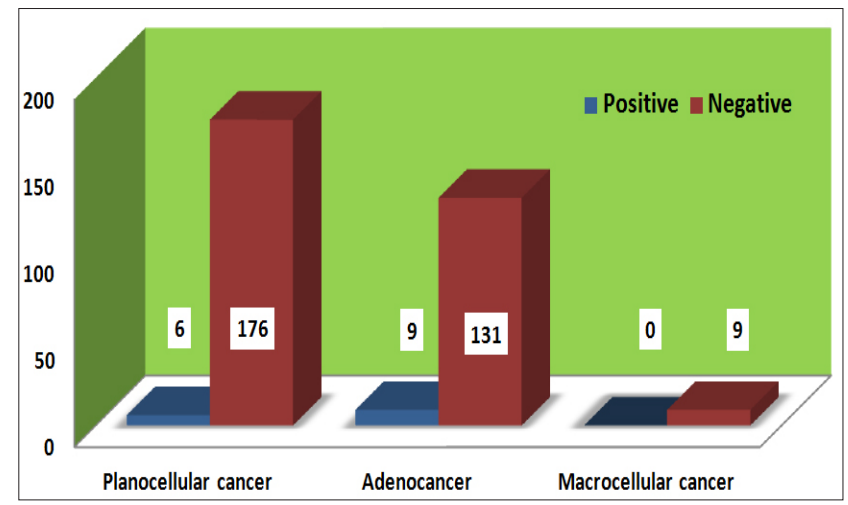

Value of $\chi 2$ test was 1.55 while $\mathrm{p}=0.46$ which was $>0.05$, hence it may be stated that there was no statistically significant connection between the type of tumor and $\mathrm{N} 1$ metastasis.

Level N2 of lymph nodes was positive in $4.53 \%(15 / 331)$ patients who suffered from lung cancer, while the same was negative in $95.47 \%(316 / 331)$ cases, which is shown in Graph 3.

Graph 3. Frequency of N2 metastasis in relation to the sort of tumor

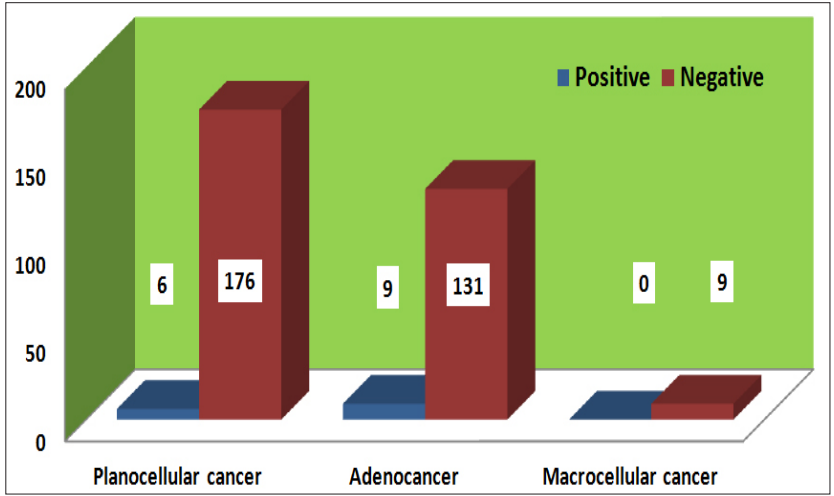

The value of $\chi 2$ test was 2.33 , while $\mathrm{p}=0.32$, and therefore it was bigger than given 0,05 , which means that there was a statistically significant connection between the type of tumor and N2 metastasis.

\section{Discussion}

Long-term cumulative effect of a great number of potent cancers, long developing flow of the disease and a hidden clinical picture represent the reason for detection of the disease in an advanced phase. Analysis of the age of our 
examined group has showed that that the one in the total number of the operated patients was 62.69 years (male 63.52; female 59.81). A patient at the age of 82 , who has undergone the operation, is the proof of the above mentioned. The occurrence of the disease in a female patient at the age of 21 is explained by a genetic tendency of inheriting, and it has earlier been proved in a great number of studies. ${ }^{2,3,12}$

Out of the total number of the operated patients (331), the participation of people of male gender (257) was significantly higher in relation to female gender (74), and the reason for this may be found in more frequent smoking habits of males as well as the professional orientations and the fact that the male gender is more exposed to cancer. ${ }^{3,12,13}$ Statistically analyzed, there was a significant difference in average values of the age of the patients with lung cancer in relation to the gender (3.71 years) - Independent Sample Test; $\mathrm{p}=0,00$.

Taking into the consideration significantly bigger number of people of male gender in the observed group (257 vs 74), we should expect a greater representativness of planocellular cancer in relation to adenocarcinoma. However, this relation is not in a big disproportion, and it is only $182 / 140$ in advance of cancer of epithelial origin, which corresponds with the increasing frequency of occurrence of this types of tumor in female gender. ${ }^{37,12}$ Statistically, there was no significant difference in the frequency of occurrence between the two types of lung cancer $\chi^{2}$ test $=3.02 ; \mathrm{p}=0.09$.

The volume of invasion of N1 level of lymph nodes by metastatic deposits in primary tumor in $44.61 \%$ (147/331), and negativity in 55.39\% (184/331) patients, supports the ides of previously mentioned fact of late diagnosis. Statistically, there was no significant connection between the type of tumor and N1 level metastasis ( $\chi_{2}$ test $=1.55$; $\mathrm{p}=0.46$ ). N2 level of lymph nodes was positive in $4.53 \%$ $(15 / 331)$ of the operated patients, while it was negative in 95.47\% (316/331) of cases, and in our case it represents the parameter of good preoperational evaluation (cTNM). There was no statistically significant connection between the types of tumor and N2 metastasis ( $\chi 2$ test=2.33; $\mathrm{p}=0.32)$.

\section{Conclusion}

There is no significant difference in the frequency of appearance between the two most common types of nonsmall cell lung cancer, nor there is a statistical connection between the types of cancer and malignant invasion of $\mathrm{N} 1$ level of lymph nodes, while this relation is statistically significant when we talk about N1 infiltration.

\section{References}

1. International Agency for Research on Cancer, GLOBOCAN 2012 Estimated Incidence, Mortality and Prevalence Worldwide in 2012 , Section of Cancer Information

2. Malvezzi M, Bertuccio F, Levi F et al.European cancer mortality predictions for the year 2013. Ann Oncol 2013; 24:792-80o

https://doi.org/10.1093/annonc/mdto10 PMid:23402763

3. J. Ferlay, D.M. Parkin, E. Steliarova-Foucher. Estimates of cancer incidence and mortality in Europe in 2008, European Journal of Cancer; 2010: 765-781 https://doi.org/10.1016/j.ejca.2009.12.014 PMid:20116997

4. Tsoi CT, Tse LA. Professional drivers and lung cancer: a systematc review and metaanalysis. Occup Environ Med. 2012; 69(11). 831-6

https://doi.org/10.1136/oemed-2012-100666 PMid:22767869

5. Travis TD, Brambilla B, Nicholson AG et al.: The 2015 World Health Organization Classification of Lung Tumors. J Thor Oncol 10: 1243-1260, 2015

https://doi.org/10.1097/JTO.oo00000000000630 https://doi.org/10.1097/JTO.o000000000000663

6. Jones KD. Whence Lepidic? Arch Pathol Lab.Med 2013 https://doi.org/10.5858/arpa.2013-0144-HP

7. Travis WD: Pathology of Lung Cancer. Clin Chest Med 32: 669-692, 2011

https://doi.org/10.1016/j.ccm.2011.08.005 PMid:22054879

8. American Cancer Society. Cancer facts and figures 2016. Available at: http://www.cancer.org/acs/groups/ content/@research/documents/document/acspc-047079. pdf .

9. Guska S. Procjena tehničke resektabilnosti plućnog karcinoma. Opšti principi savremene torakohiruške prakse. Medicinski fakultet Univerziteta u Sarajevu; 2012: 55-65.

10. Milašinović D, Jovanović D, Tomić I, Rančić $M$, Radosavljević D, et al. Nacionalni vodič dobre kliničke prakse za dijagnostikovanje i liječenje karcinoma pluća. Beograd; 2012: 30-31.

11. Rivera C, Dahan M, Bernard A, Falcoz P, Thomas P. Surgical treatment of lung cancer in the ocogenarians. Cardio Thorac Surg. 2011: 981-988. PMid:21030267

12. Lange P, Nyboe J, Jensen G, Schnohr P, Ap-pleyard M. Relation of the type of tobacco and inhalation pattern to pulmonary and total mortality, Eur. Respir. J.; 2002: 112117.

13. Shields TW. Pathology of Carcinoma of the Lung. In: General Thoracic Surgery. Lippincott Williams and Wilkins. 2005; 6(2) :1455-1480 


\section{Odnos vrste nemikrocelularnog karcinoma pluća i infiltracije drenažnih limfnih nodusa}

\section{SAŽETAK}

Uvod: Zahvaćenost drenažnih limfnih nodusa malignim ćelijama plućnog karcinoma predstavlja osnovi preduslov metastaziranja i napredovanja bolesti. Invazivnost tumora je u zavisnosti od njegovih patomorfoloških karakteristika, od kojih vrsta ima jednu od najbitnijih uloga.

Cilj rada: Deskriptivna analiziza operativno tretiranih pacijenata, procjena učestalosti i zastupljenosti navedenih vrsta NSCLC-a u posmatranoj grupi, analiza zahvaćenosti drenažnih limfnih nodusa malignim ćelijama u zavisnosti od vrste primarnog tumora.

Ispitanici i metode: $U$ analizu je uključen 331 pacijent koji je inicijalno operativno tretiran, prilikom čega je odstranjena maligna infiltracija, uz disekciju drenažnih limfnih nodusa.

Rezultati: Od ukupnog broja operisanih pacijenata, 257 su bili muškarci, a 74 žene, prosječne starosti od 63,52 godine (2180). Odnos polne strukture oboljelih u odnosu na pol je statistički značajna ( $p=0,00)$. Odnos planocelularnog karcinoma prema adenokarcinomu je 182:140, dok je odnos drugih vrsta tumora neznatan. Statistički ne postoji značajna razlika u učestalosti dvije najčešće vrste plućnog karcinoma ( $\chi^{2}$ test= 3,02; $\left.p=0,09\right)$. Ne postoji značajna statistička povezanost između vrste tumora i N1 metastaza ( $\left.\chi^{2}=1,55 ; p=0,46\right)$, kao ni odnos vrste tumora i maligne infiltracije limfnih čvorova nivoa N2 $\left(\chi^{2}=2,33, p=0,32\right)$.

Zaključak: Ne postoji povezanost između vrste karcinoma pluća i invazije N1 i N2 nivoa limfnih čvorova.

Ključne riječi: NSCLC, vrsta tumora, limfni čvorovi 